\begin{tabular}{|c|l|}
\hline Title & MOLECULAR MECHA NISMS OF EX OCY TOSIS \\
\hline Author(s) & KUMA KURA, Konosuke \\
\hline Citation & Japanese Journal of Veterinary Research, 44(4), 238-239 \\
\hline Issue Date & 1997-02-28 \\
\hline Doc URL & http://hdl.handle.net/2115/2587 \\
\hline Type & bulletin (article) \\
\hline File Information & KJo0002398288.pdf \\
\hline
\end{tabular}

Instructions for use 
Jpn. J. Vet. Res. 44(4) : 238-239 (1997)

\title{
MOLECULAR MECHANISMS OF EXOCYTOSIS
}

\author{
Konosuke KUMAKURA \\ Life Science Institute, \\ Sophia University, \\ 7-1 Kioi-cho, Chiyoda-ku, Tokyo 102, Japan
}

Neurotrasmitter is stored in synaptic vesicles and released from nerve terminals by regulated exocytosis triggered by $\mathrm{Ca}^{+}{ }^{+}$signals. The regulated exocytosis has been dissolved in multi steps such as, docking, priming, and fusion of secretory vesicles, and thus assumed to be similar to the process of intracellular vesicular transport. Cytosolic proteins called N-ethylmalei mide-sensitive fusion protein (NSF) and the soluble NSF attachment proteins (SNAPs), and their specific membrane receptors (SNAP receptors: SNAREs) have been identified as proteins essential for docking and/or fusion of transport vesicles with target membranes (1). Recent studies have suggested that SNARE proteins are essential also for neurotransmitter release from nerve terminals. However, precise mechanisms of docking, priming, and fusion of secretory vesicles as well as the mechanisms whereby the SNARE proteins are involved are obscure.

Adrenal chromaffin cells, that release catecholamines in a $\mathrm{Ca}_{2}{ }^{+}$-dependent exocytotic manner, have been used as one of the most suitable system to study the molecular mechanism of exocytosis. Catecholamine release evoked by $\mathrm{Ca}_{2}{ }^{+}$from digitonin-permeabilized chromaffin cells can be divided into at least two sequential steps : a MgATP-dependent priming step and a MgATP-independent $\mathrm{Ca}_{2}{ }^{+}$-triggered step (2). MgATP-dependent priming seems to allow secretory granules to proceed to the $\mathrm{Ca} 2^{+}$-triggered step and only these primed granules can undergo exocytotic fusion in response to $\mathrm{Ca}_{2}{ }^{+}$in the absence of MgATP (2).

We have demonstrated, by use of digitonin-permeabilized cells, the involvement of a trimeric GTP-binding protein $(\mathrm{Go})$ in the inhibitory regulation of priming (3). The regulatory role of Go was shown to be activated by GAP43 (4). We have also suggested an essential role of actin-myosin interaction for ATP-dependent priming of exocytosis (5). We have shown that dissociation of SNAP-25 and VAMP-2 occurs during the MgATP-dependent priming step, and these proteins play some important roles in the subsequent MgATP-independent fusion step, in the permeabilized chromaffin cells (6).

Synaptotagmin (Syt) that contains two repeats of $\mathrm{C} 2$ regulatory domains is considered to be involved in neurotransmitter release (7). We have examined the effects of antibodies against $\mathrm{C} 2 \mathrm{~A}$ and $\mathrm{C} 2 \mathrm{~B}$ domains and the effects of inositol highpolyphosphate series (IHPS) on $\mathrm{Ca}^{+}{ }^{+}$- evoked catecholamine (CA) release from digito- 
nin-permeabilized adrenal chromaffin cells (8). The results suggested that IHPS binding to $\mathrm{C} 2 \mathrm{~B}$ domain arrests membrane fusion by presumably preventing interaction of Syt with phospholipids or with proteins of plasma membrane. Thus, IHPS binding to the $\mathrm{C} 2 \mathrm{~B}$ domain might keep the docked or primed vesicles away from spontaneous fusion at resting level of intracellular $\mathrm{Ca}^{+}$. Binding of the increased intracellular $\mathrm{Ca}^{+}{ }^{+}$to the $\mathrm{C} 2 \mathrm{~A}$ domain may facilitate or trigger the vesicular fusion by releasing this clamp by IHPS. This will explain a possible role of Syt (Syt-Clamp) in the mechanisms by which the secretory cells can keep a certain number of the docked/primed vesicles ready for fusion until the last moment of the signal arrival.

In this lecture, our current understanding of the mechanisms of regulated exocytosis in adrenal chromaffin cells will be discussed on the basis of those findings.

\section{REFERENCES}

1) Rothman, J. E. (1994) Nature 372, 55-63.

2) Bittner, M. A., DasGupta, B. R., and Hols, R. W. (1989) J. Biol. Chem. 264, $10354-10360$.

3) Ohara-Imaizumi, M., Kameyama, K., Kawae, et al. (1992) J. Neurochem. 58 2275-2284.

4) Vitale, N. et al. (1993) J. Biol. Chem. 268, 14715-14723.

5) Kumakura, K., Sasaki, K., Sakurai, T., et al. (1994) J. Neurosci. 14, 7695-7703.

6) Misonou, H., Nishiki, T., Sekiguchi, M., et al. (1996) Brain Res. in press.

7) Mikoshiba, K., Fukuda, M., Moreira, J. E., et al. (1995) Proc. Natl. Acad. Sci. USA, 92, 10703-10707.

8) Ohara-Imaizumi, M., Fukuda, M., Ninobe, M., et al. (1996) Proc. Natl. Acad. Sci. USA, in press. 